\title{
DOCTRINAL CHARACTERISTIC OF PUBLIC PROCUREMENT OF MEDICINES AS A FUNDAMENTAL ELEMENT OF STATE FINANCIAL GUARANTEES FOR THE PHARMACEUTICAL SPHERE
}

\author{
Oksana Strelchenko', Iryna Lychenko², Liubov Shevchenko
}

\begin{abstract}
The aim of the article is to study theoretical, methodological, and doctrinal approaches to public procurement of medicines and on this basis to determine ways to improve domestic legislation in this sphere. The subject of the study is public procurement of medicines. Methodology. The study is based on general scientific and special-scientific methods and techniques of scientific knowledge. The historical and legal method enabled to determine the preconditions for public procurement of medicines as a fundamental element of state financial guarantees for the pharmaceutical sphere in Ukraine and in the world, as well as the development of scientific and theoretical views on the nature, problems, and methods of public procurement of medications. The comparative legal method enabled to compare doctrinal approaches to public procurement of medicinal products. The systemstructural method contributed to the consideration of public procurement of medications as a fundamental institutional and functional element of state financial guarantees for the pharmaceutical sector. The methods of grouping and classifying were the basis for the author's approach to public procurement of medicines for the most important and practically significant criteria. The technical legal method enabled to interrogate the state of affairs in the statutory and legal regulation of the national system of public procurement of medications, to identify its disadvantages, gaps, contradictions and miscalculations, as well as to develop recommendations aimed at their elimination. The results of the study revealed that public procurement of medicines should be considered as an activity of a public administration or specialized agencies authorized by it, aimed at purchasing medicinal products by the procurer funded from taxpayer's money and preserving the health of citizens via a transparent control by the state (via the Prozoro system). Practical implications. In the study: first, the key aspects of the genesis of public procurement of medicines are outlined; second, scientific approaches to their characteristics, available in the special literature, are analysed and compared; third, the author's original perspective concerning legislative regulation and consolidation in the current legal regulations is substantiated. Relevance/originality. The original author's approach to the doctrinal principles of public procurement of medications is the basis for developing the most promising areas of improvement of domestic legislation in this sphere.
\end{abstract}

Key words: medicines, financing, pharmaceutical industry, tenders, state budget.

JEL Classification: I13, H61

\section{Introduction}

In modern circulation of medicines and pharmaceutical services for the population of Ukraine, one of the most important problems is the efficient use of state financial resources to provide health care institutions with medicinal products and medical devices fully. State regulation of health care includes the public procurement system. Public procurements are a promising and important macroeconomic regulator forming a fully-fledged competitive environment in health services, and implementing stabilization policy in this sphere (Dolinovskyi).

\footnotetext{
Corresponding author:

${ }^{1}$ National Academy of Internal Affairs, Ukraine.

${ }^{2}$ Lviv Polytechnic National University, Ukraine.

${ }^{3}$ National Academy of Internal Affairs, Ukraine.

E-mail: strel1977@ukr.net
}

However, under strict financial constraints, a new qualitative medical provision for the population is impossible without the efficient use of resources aimed at public procurement of medicines, medical equipment and modern conditions for medical institutions. First, the question arises about the timely provision of patients with the necessary medicines that enter the Ukrainian market through the appropriate public procurement procedure. In Ukraine, the state of affairs in public procurement of medicines is of concern to not only representatives of law enforcement bodies, business organizations and the Ukrainian public, but 
also representatives of international organizations and funds (Dolinovskyi).

The improvement of the pharmaceutical industry in the area of development and implementation of the most effective and safe medications is a priority for many leading countries of the world and the most famous pharmacological companies. This is because of the social significance of the products of the industry, changes in the demographic situation in all countries of the world due to the aging of the population, increase in the incidence among people, especially the elderly. According to the UN, in countries of the Organization for Economic Cooperation and Development (OECD), which includes 34 countries (mainly from Europe and North America), the population aged 65 and over is more than $17 \%$ of the total, and by 2019 , according to the forecast, will increase by $20 \%$. The share of the young and able-bodied population is decreasing. In 2020 , about $9.4 \%$ of the populations (719.4 million people) will be people aged 65 and over, compared with $7.3 \%$ (477.4 million) in 2015 (Human Development Report, 2009; Franklin, Andrews, 2013).

Inlegal science, the issues of procurement of medicines were studied by domestic and foreign scientists, such as N. O. Vetiutneva, S. H. Ubohov, O. V. Kuzmenko, V. K. Kolpakov, H. H. Pylypenko, A. P. Radchenko, M. V. Rymar, O. H. Strelchenko, L. O. Fedorova and others. However, public procurement of medicines is not considered enough, consequently, the chosen topic of the scientific article is of timeliness and importance.

Therefore, understanding the doctrinal approaches to public procurement of medicines becomes relevant and constructs the aim of this article. For its successful achievement, the following tasks should be solved: first, to outline the key aspects of the genesis of public procurement of medicines; second, to analyse the perspectives available in the special literature in relation to public procurement of medicines; third, to propose an author's original approach to public procurement of medicines.

\section{Main material}

In Ukraine, the current state of affairs of public procurement of medicinal products and medical devices in the healthcare sector poses a threat to the timely provision of patients with quality, safe, and effective medicinal products and medical devices, which leads to a deterioration in public health and an increase in mortality rates.

In Ukraine, public procurement of medicinal products and medical devices is a complex procedure with many components and is regulated by legal regulations, in particular the Law of Ukraine "On Public Procurement," in which medicinal products and medical devices are considered as any other goods, by other laws and subsidiary laws in the health care. This is unacceptable in relation to medicinal products and medical devices.
Therefore, to interrogate public procurement in medication circulation, the genesis of determinants of "medicines", "public procurement" and "public procurement of medicines" should be studied.

For example, medicines are one of the most economically attractive products. However, it should be considered that medicines are not an ordinary commodity but an important means of ensuring constitutional human rights to health and life.

It is important to explore the term "medicines" to assure the quality, safety, and efficiency of medication circulation.

Article 2 of the Law of Ukraine "On Medicines" defines a "medicinal product" as any substance or a combination of substances (one or more API and excipients) having properties for treating or preventing diseases in human beings, or any substance or a combination of substances (one or more API and excipients) that may be used to prevent pregnancy, restore, correct or modify physiological functions of human beings by pharmacological, immunological or metabolic action or to make medical diagnosis (Pro likarski zasoby).

The Free Encyclopaedia Wikipedia interprets the term "medication" (also referred to as "medicine," "pharmaceutical drug") as substances or a combination of substances used for preventing, diagnosing, treating diseases, preventing pregnancy, eliminating pain; derived from blood, blood plasma, organs and tissues of human beings or animals, plants, minerals, chemical synthesis (pharmaceuticals, drugs or medicines) or with the use of biotechnologies (vaccines).

The Pharmaceutical Encyclopaedia defines a "medicinal product" as a product of pharmaceutical activity having a certain composition, a certain dosage form, packaging, expiration date. It is assigned to a sick person with a view to diagnosing, treating or relieving the symptoms of the disease or changing the condition of organism's physiological functions, as well as preventing, for example, contraceptives, stress drugs, etc. For medicinal products, strict requirements are put forward (therapeutic efficacy, safety, the accuracy of dosing active substances, stability, etc.), and their usage in medical practice is allowed only after state registration (Farmakolohichna entsyklopediia).

Therefore, in this interpretation, the main feature is the action, composition, form, packaging and expiration date, which, in our opinion, do not convey a significant meaning. Moreover, the definition of the origin and quality of the pharmaceutical product would be more appropriate.

Scientists-pharmacologists suggest a more formalized and legitimated definition of a medication.

Medicinal product is a pharmacological agent of natural, synthetic or semi-synthetic origin having properties to prevent pathological process or to cause a therapeutic effect on diseases and is officially authorized for treating patients by the official body of 
the state (Chekman, Horchakova, Kazak, 2011). In this interpretation, therapeutic properties are recognized as a special feature of medicinal products, moreover, the official authorization by the state body, that is, the registration of the medication and its origin, is underlined as another important feature.

According to M.I. Yabluchanskyi and V.M. Savchenko, a "medicinal product" is a pharmacological agent that, in the prescribed manner, is authorized by the authorized body for treating, preventing or diagnosing pathological conditions (diseases and clinical syndromes) in medical and veterinary practice (Abduieva, Bychkova, Bondarenko, 2011).

This definition emphasizes that medications should be legally permissible (in our case, be included in the State Register of Medicinal Products) for the corresponding purposes, but does not describe real therapeutic properties for medical use.

It should be noted that the proposed restriction of certain medicines with the introduction into the State Register of Medicinal Products constrains business entities engaged in pharmaceutical activities. This affects the development of new medications and persons promoting a new, modern medicine in the medication market because the subject of their activities is not clarified. The medicinal product should be opposed to non-medicinal to solve this problem of pharmacists. In various works, it is called a pharmacological preparation, a medicinal substance, a medicinal compound, a pharmacological agent, a clinical sample, etc. The main difference from the medicinal product is that it is not included in the State Register of Medicinal Products, and therefore, it is not permitted for use in Ukraine. The pharmacological (non-medicinal) agents are medicines that are under development, inspection and testing, foreign medicines not authorized in Ukraine, medicines authorized to use in Ukraine earlier, but now authorization is absent (cancelled or expired), etc. (Zyma, 2015).

According to H. R. Dzvoniv, N. I. Makhonko, medicinal products are substances used for preventing, diagnosing, treating the disease, preventing pregnancy, derived from blood, blood plasma, as well as organs, tissues of human beings or animals, plants, minerals by synthesis or biological techniques (Dzvoniv, Makhonko).

The identified determinants reveal that the lexeme "medicinal products" needs to be clarified because of its significant overload. Therefore, the authors suggest an original determinant of a "medicinal product" as a substance or a combination of substances of organic (e.g. chloroform, ethyl chloride) and inorganic (e.g. oxygen and odrogen) origin with the corresponding pharmacological action, which are used for the prevention, diagnosis, treatment of diseases and prevention of unwanted pregnancy.

The next research category is the determinant of "public procurement."
Therefore, "public procurements" are procurements of goods, works, and services by the customer from public funds or on behalf of a public institution.

The category "public procurement" can be also interpreted as:

- procurement carried out by the state or its separate subdivision;

funded by the state;

- carried out in the interests of the state and the procuring body;

- the state controls the procurement (Shcho take derzhavni/publichni zakupivli?).

Other interpretations of "public procurement" follow. Public procurements include the following aspects:

- procurement is carried out by the public administration;

- the purchase of goods and services is funded from taxpayers' money;

- procurement is carried out in the interests of citizens for the provision of quality services by a public administration or a state-owned enterprise;

- citizens can participate in controlling public procurement (Shcho take derzhavni/publichnizakupivili).

Hereinafter, the term "public procurement" means purchases carried out in Ukraine before today's reform. At the same time, "public procurement" means open and public tenders, which should become a reality of modern health care reform in general (Shcho take derzhavni/publichni zakupivili?).

Therefore, the authors suggest an original definition of the determinant of "public procurement" as the activities of the public administration or its authorized structural units, aimed at procurement of goods, works, and services by the customer funded from the taxpayers' money and carried out in the interests of citizens via a transparent state control (via the Prozoro system).

In the study, doctrinal characteristics of the category "public procurement of medicinal products" should be made because it is not studied by scientists and is not defined by the legislation.

Therefore, "public procurement of medicinal products" should be understood as the activities of the public administration or specialized agencies authorized by it, aimed at procurement of medicinal products by the customer funded from the taxpayers' money and carried out in the interests of preserving the health of citizens via a transparent state control (via the Prozoro system).

However, it should be noted that the underlying and well-known problems in public procurement of medicinal products and medical devices are corruption and limited competition leading to public procurement of medicinal products and medical devices at inflated prices. Over the last few years, many issues have been accumulated at different decision-making levels leading to a violation of the principle of equality of access to medicines and medical devices, and a state of affairs 
when patients remain without proper treatment and epidemics occur though they can be prevented by vaccination. Measures have been taken to introduce best practices from other countries (for example, the use of a reference price pool, piloting of reimbursement), but these initiatives have been discontinued.

As the problems in public procurement of medicinal products and medical devices constitute life-threatening situation, the existing system of public procurement of medicinal products and medical devices is inadmissible to maintain.

Considering that the proper implementation of any public procurement reform takes time, and provision of the population with the necessary medicinal products and medical devices should be permanent and continuous, the Verkhovna Rada of Ukraine adopted a decision on the temporary, until March 31, 2019, transfer of public procurement of medicinal products and medical devices from the Ministry of Health of Ukraine to specialized procurement organizations, by adopting the Laws of Ukraine no. 269-VIII as of March 19, 2015, "On Amendments to some Laws of Ukraine on ensuring timely patient access to appropriate medicinal products and medical devices through the implementation of public procurement with the involvement of specialized organizations carrying out procurement" and no. 332-VIII as of April 9, 2015, "On Amendments to the Tax Code of Ukraine regarding the exemption from taxation of certain medicinal products and medical devices." In addition, in the implementation of this procurement mechanism, a number of other legal regulations were adopted and/or amendments were made to the relevant legal regulations. Therefore, on March 31, 2018 , the countdown of the last year of procurement of medicinal products and medical devices with the involvement of specialized procurement organizations started. The date of March 31, 2019, is determined by legislation as the deadline for such procurement.

The development of public procurement of medicines reveals that in 2014 the Association Agreement between Ukraine, on the one part, and the European Union, the European Atomic Energy Community and their member states, on the other part, provides for the creation of a Deep and Comprehensive Free Trade Area. To carry out the above-mentioned Agreement, in the part of public procurement reform, the Cabinet of Ministers of Ukraine approved the Strategy for Reforming the Public Procurement System (Cabinet of Ministers of Ukraine) ("Roadmap"). According to these documents, one of the most important and promising areas for reforming the public procurement system is the introduction of EU experience in centralizing procurement through the creation of a centralized procuring organization in Ukraine (Cabinet of Ministers of Ukraine).

Public procurement of medicinal products and medical devices in Ukraine is carried out through centralized and decentralized systems. The decentralized system provides with the opportunity to take into account the needs of territorial communities of end users of goods and services procured. However, such a system is rather ineffective since it limits the possibilities for obtaining such benefits as saving through the combination of total procurements and time expenditures. Moreover, such a system is not effective due to a significant number of low-paid workers, for whom procurement procedures are additional burdens that are above main occupational responsibilities, which leads to risks of corruption.

Numerous decisions of the Antimonopoly Committee on complaints about public procurement procedures of medicinal products and medical devices in the health care, with the statement of discriminatory conditions, indicate a potential customer engagement due to low motivation and/or insufficient qualification of specialists who formulate technical tasks and conduct procurement procedures.

The central procurement system of the $\mathrm{MOH}$ and decentralized procurement at the regional level has been ineffective for many years (unacceptably high prices, delay in tendering, the reluctance of companies to bid, which led to a reduction in competition, lack of medicines, etc.). Furthermore, the problem of corruption is well known.

The problem of the public procurement system in the health sector is multifaceted. The problems arise at stages of: a) the formation of a sectoral standard in the health care; $b$ ) the formation of a list of medicinal products and medical devices to be procured; c) the selection of medicinal products and medical devices for procurement; d) the formation of information on the subject of procurement and tender documentation, which may contain discriminatory conditions indicating that the documentation is being prepared for a particular participant; e) the activities of the tender committee, authorized to make changes to the information on the subject of procurement; g) public procurement of medicinal products and medical devices.

At the same time, considering the importance of reforming the stage of preparation for procurement, this Concept aims at solving problems that arise at the stage of public procurement of medicinal products and medical devices.

To ensure transparency and explicability of costs during public procurement of medicinal products and medical devices, it is necessary to eliminate the shortcomings of legislative regulation at the specified stages of procurement, which can be used by unscrupulous customers and participants in procurement for corruption purposes and predation.

However, the problem of underfunding, a significant effect of the exchange rate fluctuations on total public procurement of medicinal products and medical devices of foreign production and the lack of longterm multi-year planning of such procurements is well known. 


\section{Conclusions}

Therefore, currently, public procurements of medicinal products are performed on a general basis only according to the Law of Ukraine "On Public Procurement", where medicinal products are defined as "any other goods". In this case, the provisions and requirements of the Laws of Ukraine "On Medicines," "On Amendments to some Laws of Ukraine on ensuring timely patient access to appropriate medicinal products and medical devices through the implementation of public procurement with the involvement of specialized organizations carrying out procurement," "On Amendments to the Tax Code of Ukraine regarding the exemption from taxation of certain medicinal products and medical devices" and corresponding Resolutions of the Cabinet of Ministers of Ukraine, Orders of the Ministry of Health of Ukraine, which determine the special requirements for their procurement, etc. must also be considered. Moreover, first, the Law of Ukraine "On Public Procurement" should be supplemented by the author's determinant of "medicinal products" that are the subject of public procurement, to substitute attribution to "any other goods" by identification; second, Article 1 of the Law of Ukraine "On Medicines" should be supplemented by the author's category "public procurement of medicinal products."

\section{References:}

Dolinovskyi, Yu. S. Osoblyvosti provedennia publichnykh zakupivel tovariv, robit i posluh u sferi okhorony zdorovia [Features of public procurement of goods, works and services in the healthcare]. Lviv Polytechnic National University Institutional Repository. Retrieved from: http://ena.lp.edu.uac/501 (in Ukrainian)

Human Development Report 2009. Retrieved from: http://www.hdr.undp.org

Franklin, D., Andrews, J. (Eds.). (2013). Myrv 2050 godu [The world in 2050]. M.: Mann, Ivanov and Ferber, Exmo. (in Russian)

Pro likarski zasoby [On medicines] (Law of Ukraine no. 123/96-VR of April 04, 1996) (Zi zminamy ta dopovnenniamy, vnesenymy Zakonom Ukrainy vid 31 trav. 2016 r. № 1396-VII) (Amended and supplemented by the Law of Ukraine no. 1396-VII of May 31, 2016). Vidomosti Verkhovnoi Rady Ukrainy [Bulletin of the Verkhovna Rada of Ukraine], 22, Art. 86. (in Ukrainian)

Farmakolohichna entsyklopediia [Pharmacological encyclopedia]. Retrieved from: https://www.pharmencyclopedia.com.ua/ article/3096/obig-likarskix-preparativ (in Ukrainian)

Chekman, I. S., Horchakova, N. O., Kazak, L. I. et al. (2011). Farmakolohiia: pidruchnyk dlia studentiv medychnykh fakultetiv [Pharmacology: teaching manual for students of medical faculties]. Vinnytsia: Nova Knyha. (in Ukrainian)

Abduieva, F. M., Bychkova, O. Yu., Bondarenko, I. O. et al. (2011). Klinichna farmakolohiia: pidruchnyk dlia studentiv i likariv [Clinical pharmacology: Textbook for students and doctors]. M. I. Yabluchanskyi, V. M. Savchenko (Eds.). Kh.: V. N. Karazin KhNU. (in Ukrainian)

Zyma, O. T. (2015). Likarski zasoby yak predmet pravovykh vidnosyn [Medicines as a subject of legal relations]. Porivnialno-analitychne parvo, 4, 232-234. (in Ukrainian)

Dzvoniv, H. R., Makhonko, N. I. Medychne pravo: navchalnyi posibnyk [Medical law: teaching manual]. Retrieved from: http://yport.inf.ua/meditsinskoe-pravo-uchebnoe.htm (in Ukrainian)

Shcho take derzhavni/publichni zakupivli? [What are public/public procurement?]. Retrieved from: http://prava-lyudyny.org/shho-take-derzhavni-publichni-zakupivli/ (in Ukrainian)

Cabinet of Ministers of Ukraine. Stratehiia reformuvannia systemy publichnykh zakupivel [The strategy for reforming the public procurement system] (Order no. 175 of February 24, 2016). Ofitsiynyi visnyk Ukrainy, $23,920$. (in Ukrainian) 